\title{
Statistical Analysis for Contract Cheating in Chinese Universities
}

\author{
Yuexia Wang (D) and Zhihuo Xu*(D) \\ School of Transportation, Nantong University, Nantong 226019, China; venus@ntu.edu.cn \\ * Correspondence: xuzhihuo@ntu.edu.cn
}

Citation: Wang, Y.; Xu, Z. Statistical Analysis for Contract Cheating in Chinese Universities. Mathematics 2021, 9, 1684. https://doi.org/ $10.3390 /$ math 9141684

Academic Editors: Gregorio Giménez Esteban and Javier Valbuena

Received: 24 June 2021

Accepted: 14 July 2021

Published: 17 July 2021

Publisher's Note: MDPI stays neutral with regard to jurisdictional claims in published maps and institutional affiliations.

Copyright: (c) 2021 by the authors. Licensee MDPI, Basel, Switzerland. This article is an open access article distributed under the terms and conditions of the Creative Commons Attribution (CC BY) license (https:// creativecommons.org/licenses/by/ $4.0 /)$.

\begin{abstract}
Contract cheating refers to students using third-party online resources to complete their coursework. It is not only a unilateral result of the student, but also has a relationship with educators, as well as social resources. However, little work has been performed to analyze the complex behavioral aspects behind contract cheating in Chinese universities. To this end, this article presents a statistical analysis of contract cheating in Chinese universities. First, a unique parallel survey of educators and students was conducted to collect data from August 2018 to August 2020. Next, statistical analyses were performed to explore students' experiences and attitudes toward contract cheating and the contextual factors that relate to these behaviors. Additionally, Pearson correlation tests were conducted on the survey data to find potential factors for contract cheating. Finally, a multivariate statistical technique, partial-least-squares regression (PLSR), was applied to interpret the results. The results of the statistical analysis showed that the main motivation for contract cheating is to receive good grades (the correlation coefficient $\rho$ is 0.1309 ) from the perspective of students personal learning; from the side of university management, clear regulations $(\rho=-0.1378)$, penalties for cheating $(\rho=-0.1275)$, and the use of cheating-detection software $(\rho=-0.1186)$ can directly reduce cheating; from the perspective of teachers' teaching, lecturers' feedback on cheating on assignments $(\rho=-0.1510)$ can effectively reduce students' cheating behavior; in addition, increasing students' sense of achievement in course learning $(\rho=-0.2619)$ also helps to reduce the probability of cheating.
\end{abstract}

Keywords: academic cheating; contract cheating; partial-least-squares regression (PLSR); Pearson correlation tests; statistical analysis

\section{Introduction}

In June 2018, a total of 81 students at Guangxi University of Science and Technology copied and pasted extensively in their coursework [1]. In September 2018, Professor Su of the School of Humanities at the University of the Chinese Academy of Sciences found that 22 students copied much material from websites to complete their final coursework, but did not cite the sources correctly [2]. These phenomena are becoming more and more frequent [3]. This kind of behavior was firstly coined as contract cheating by Clarke and Lancaster [4], to describe the process by which students outsource their coursework to a third party online. Contract cheating providers exist as businesses with common goals to profit by taking advantage of students' inability to meet their academic requirements. It has now evolved to cover a range of outsourcing student coursework to third parties, regardless of the third party's relationship with the student and whether or not money was exchanged $[5,6]$.

Contract cheating has spawned higher education crises in the sustainability of learning and teaching. Therefore, there is great concern about the increase in plagiarized coursework submitted by students in higher education. Many research works have been performed to study contract cheating. Badge et al. [7] developed an effective plagiarism-detection service to identify plagiarism in the University of Leicester, U.K. They also suggested 
that the detection tool cannot always detect copying from peer-reviewed journal articles due to password protection for access. However, the growing database of student work within the detection software can provide a match for copying from such a source. Butakov and Scherbinin [8] proposed a new architecture for plagiarism-detection tools that can be applied to many different types of digital submissions, from plain or formatted text to audio podcasts. Yang et al. [9] applied an active learning approach that involves students and teachers in finding the reasons why code similarities occur in programming assignments to avoid being judged as plagiarism. An analysis of student behavior found that $15 \%$ of international students currently have hired someone to complete at least one assessment for them [10]. Lines [11] examined the nature, motivations, and prevalence of substantive editing and suggested two possible avenues to address the growing problem of abuse. Rowland et al. [12] found that contract cheat sites used a variety of interactive, informative, and trustworthy features designed to persuade students to use their low-cost and customizable services. Substantive editing poses a threat to the integrity of Australian universities because of its impact on postgraduate students, particularly the English as a second language postgraduate community.

However, academic dishonesty is changing as methods and available technologies evolve and as control and inspection strategies vary $[13,14]$. For example, the proliferation of the World Wide Web, the popularity of smartphones, and widespread access to social media (Twitter, Facebook, YouTube, microblogs, WhatsApp, WeChat, Tencent QQ, etc.) and its rich resources are changing the nature and extent of the problem [15-17]. One study by Ellery [18] investigated the role of electronic information sources in influencing plagiarism in a first-year geography module essay assignment at the University of KwaZulu-Natal, South Africa. One way to improve contract cheating detection was suggested through the use of Turnitin's Authorship Investigate tool, which compares student-submitted assignments with their previous work. Liu [19] evaluated the design and efficacy of a learning and plagiarism avoidance tutorial system for paraphrasing and citing in English. Reference [20] demonstrated that software can improve detection rates for contract cheating, and therefore suggested that software may be an effective component of an institutional strategy to address contract cheating. Sefcik et al. [21] explored the structure and administration of academic integrity education programs in selected Australian and New Zealand institutions. Reference [22] studied how educators and students perceive the differences in the ease of cheating during paper-based examinations and electronicbased examinations. Besides attitudes and the understanding of cheating, Tremayne and Curtis [23] reported that self-control, age, and self-imposed pressure predict plagiarism over and above perceptions of seriousness and understanding. Amigud and Lancaster [24] analyzed a dataset of 5000 messages posted on Twitter by 10 contract cheating services to explore the reasons why students seek to outsource their academic work. Kauffman and Young [25] examined how the copy-and-paste function impacted digital plagiarism in real time. Reference [26] used cluster analysis to find that materialism and performance goal orientation discriminated all participants into high and low willingness to cheat clusters. Recently, Druică et al. [27] explored the link between academic dishonesty and economic delinquency, using a partial-least-squares approach.

Questionnaires are the most common and effective research instrument for understanding and studying a series of behaviors. Some excellent works have reported the contract cheating rate by using different survey tools, definitions, and behaviors. It has been found that it contains many different methods, modes, and purposes and has different levels of student participation around the world. Bretag et al. reported $5.78 \%$ in Australia [5,28,29] 30.6\% was reported in Romania and 8\% in the Czech Republic. Amigud and Lancaster [30,31] performed an analysis of market demand for contract cheating services on twitter. They found that students are be willing to pay $\$ 33.32$ per 1000 words for typical requests of essay writing. In a recent poll by Sentio, 160 students admitted to cheating in the most important higher education institutions of Norway [22]. Awdry [32] conducted the first international study undertaken to look into the varying outsourcing behaviors. 
The results showed that a substantially higher proportional rate of $45.6 \%$ was reported in Ukraine, 28.9\% in Hungary, 5.3\% in Sweden, and 7.5\% in Australia. There are many other reasons why students engage in academic misconduct. For example, Zhang and Yin [33] investigated collaborative cheating among Chinese college students and revealed positive effects of peer influence on collaborative cheating attitudes and behaviors.

From the above, contract cheating in universities is a complex behavior. It is important to investigate contract cheating in student coursework from both the student and faculty side. This is because it is a typical teaching process. This process requires the dedication of the teacher and the active learning of the students. Therefore, the teacher's perception of and response to plagiarism is a direct factor regarding whether or not a student chooses to plagiarize. However, little work has been performed to analyze the complex behavioral aspects behind contract cheating in Chinese universities. Therefore, this article presents the preliminary descriptive statistical results of a survey of university students and teachers in China. Specifically, the research questions and the corresponding hypotheses are raised as follows:

- What is students' perception of cheating and plagiarism on assignments?

- How likely are students from different years of university to outsource their coursework?

- What effects do cheating and noncheating have on student learning outcomes?

- How do educators perceive and respond to the behaviors of contract cheating?

- What are the motivating factors for cheating behaviors?

\section{Materials and Methods}

\subsection{Materials}

Two parallel questionnaires, one for students and one for teachers, were conducted at four different types of Chinese universities: University of the Chinese Academy of Sciences, double first-class universities, national key universities, and ordinary universities. The characteristics of these four types of Chinese universities are as follows. Founded and run by the Chinese Academy of Sciences, the University of the Chinese Academy of Sciences is the most prestigious graduate school of science and engineering in China. In 2014, the University of the Chinese Academy of Sciences began recruiting undergraduate students. National key universities have brilliant teachers who really know what they are doing. Ordinary universities also have distinguished professors who really know what they are doing. There is virtually no difference between students in the top $5 \%$ of the ordinary university and students in the top $50 \%$ of the national key universities. However, national key universities have a higher percentage of students with very strong academic skills. Teachers at national key universities can assume that all students are very smart and hard working, and therefore have higher expectations of their students. For example, this may mean faster lectures, more assignments, and harder tests. Double first-class universities are a combination of world-class universities and first-class academic disciplines, designed by the China government in 2015 to fully develop Chinese elite universities and their various faculties into world-class institutions by the end of 2050. From the above, it can be seen that the survey of students and the faculty of these four types of universities can reflect more comprehensively the treatment of contract cheating by Chinese university students.

The survey for the students was designed in five sections: (a) background questions, including participant institution and year of college; (b) questions related to the participant's perceptions about the contract cheating and related experiences; (c) questions related to potential reasons for cheating; (d) questions about the participant's teaching and learning environment related to cheating; (e) questions related to the learning outcome with cheating and without cheating in coursework. The version of the questionnaire for teachers was similar to the student's version except that it did not include the fifth part. Tables 1 and 2 show the main questionnaires for students and educators. In Table 1, Questions 1-5 relate to participants' perceptions and related experiences; Question 6 addresses potential causes of cheating; Questions 7-11 relate to participants' teaching and learning environment; 
and Questions 12-14 address learning outcomes in the current environment of cheating behavior.

The survey was conducted from August 2018 to August 2020 using an online questionnaire survey. Students and teachers were invited through social media to various WeChat groups and Tencent QQ groups. More than 3000 students were invited to participate by QQ groups containing a link to the online survey, and 447 completed the whole survey. A total of 1103 teachers were invited, of which 62 completed the survey. Participation in the survey was voluntary and anonymous, and participant data were confidential. In order to better protect the privacy of participants, demographic information such as the age and gender of respondents was not collected.

Table 1. Main questionnaire for students.

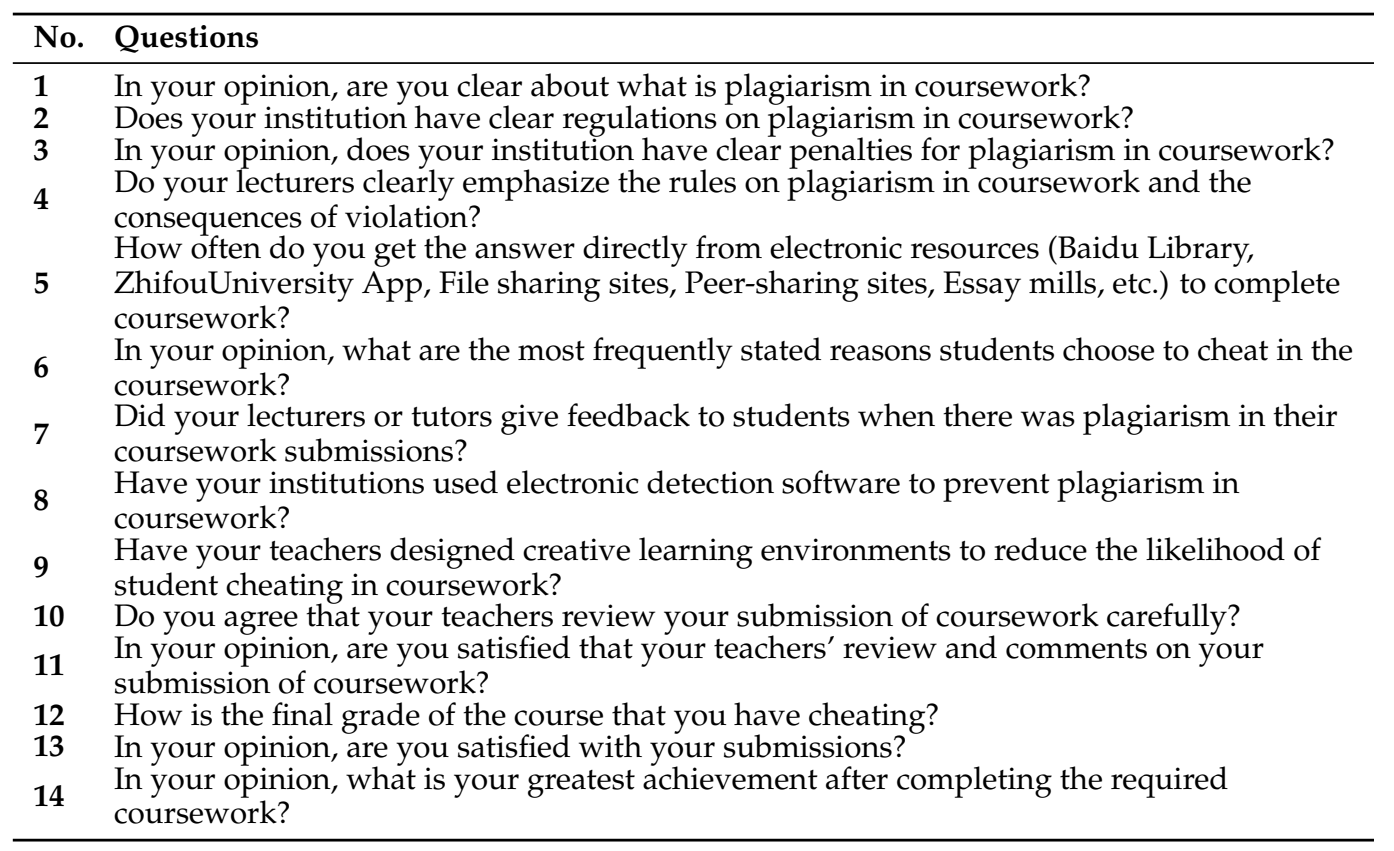

Table 2. Main questionnaire for teachers.

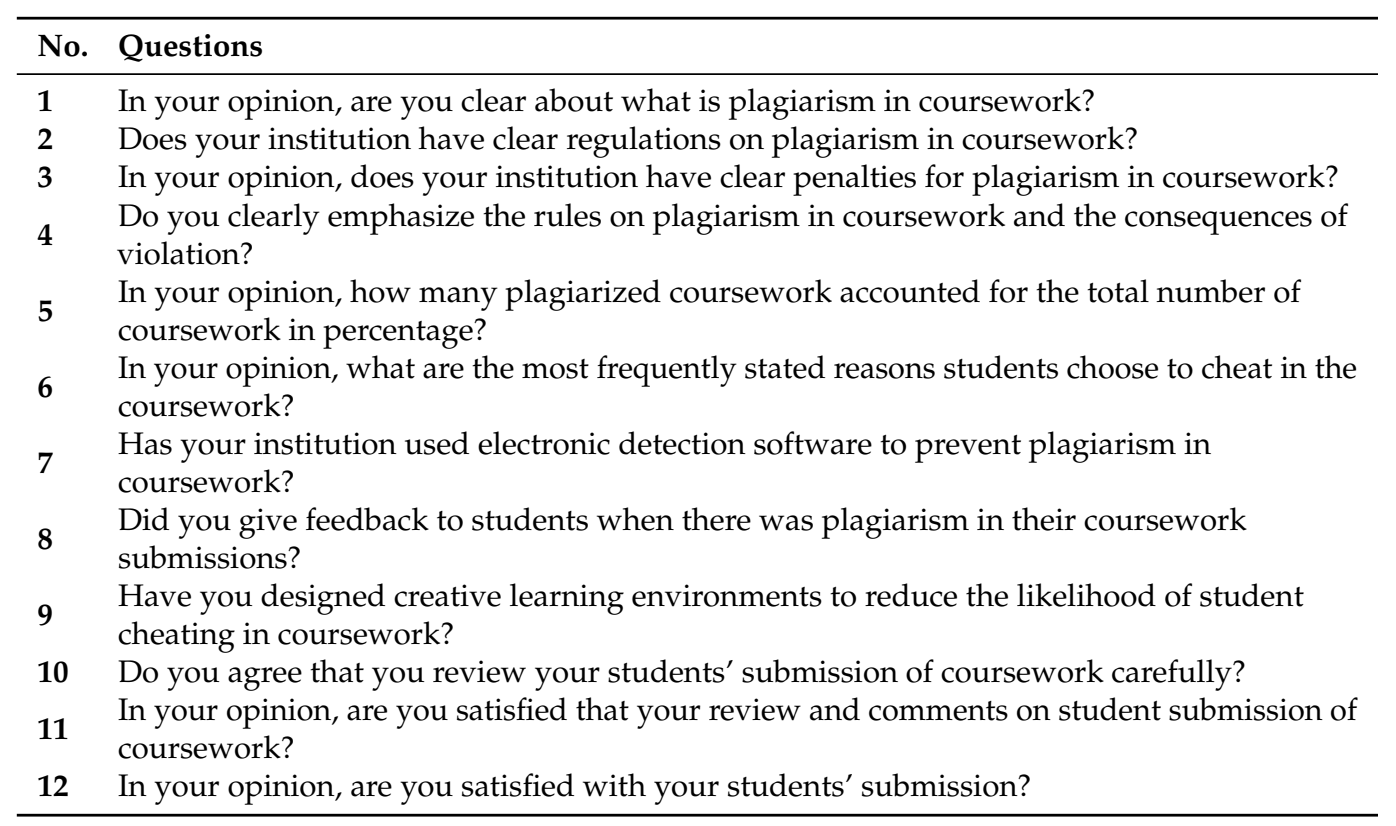




\subsection{Methods}

After collecting the survey data, statistical analyses were firstly conducted to explore students' experiences and attitudes toward contract cheating and the contextual factors that relate to these behaviors. In particular, in order to study the relationship among contract cheating and individuals, teachers' parameters, and institutional platforms, linear regressions were performed by using Pearson's linear correlation.

Additionally, Pearson's correlation coefficient measures the degree of linear correlation between two quantitative variables [34]. Given $N$ samples of two parameters $\mathbf{x}$ and $\mathbf{y}$, the coefficient $\rho_{x y}$ is calculated as:

$$
\rho_{x y}=\frac{N \sum_{i=1}^{N}\left(x_{i} y_{i}\right)-\sum_{i=1}^{N} x_{i} \sum_{i=1}^{N} y_{i}}{\sqrt{N \sum_{i=1}^{N} x_{i}^{2}-\left(\sum_{i=1}^{N} x_{i}\right)^{2}} \sqrt{N \sum_{i=1}^{N} y_{i}^{2}-\left(\sum_{i=1}^{N} y_{i}\right)^{2}}}
$$

where $x_{i}$ and $y_{i}$ are the $i$ th sample data.

Finally, a multivariate statistical technique, partial-least-squares regression (PLSR) [35], was applied to analyze the data. Assuming that the matrix $X$ represents the potential factors associated with contract cheating and $y$ is the frequency of contract cheating, the linear regression estimates between $X$ and $y$ are constructed as:

$$
y=\bar{X} \beta+\beta_{0}
$$

where the matrix $\bar{X}$ is column normalized on the matrix $X$ and $\beta$ and $\beta_{0}$ are the regression coefficients of partial-least-squares (PLS).

\section{Results}

The survey was distributed in a number of Chinese universities. There were 28 participants from the University of the Chinese Academy of Sciences, 70 participants from double first-class universities, 62 participants from national key universities, and 349 participants from ordinary universities. The details of the number of teachers and students who participated in the questionnaire are shown in Table 3.

Table 3. Number of teachers and students participating in the survey.

\begin{tabular}{ccc}
\hline & & $\begin{array}{c}\text { \% Engaged } \\
\text { (Number Engaged/Total Responses) }\end{array}$ \\
\hline \multirow{2}{*}{ Teachers } & & $12.18 \%$ \\
& $(n=62 / 509)$ \\
\hline \multirow{3}{*}{ Students } & Freshman & $15.91 \%$ \\
& Sophomore & $(n=81 / 509)$ \\
& Junior & $15.32 \%$ \\
& Senior & $(n=78 / 509)$ \\
& & $13.75 \%$ \\
& Graduate Student & $(n=70 / 509)$ \\
& & $23.18 \%$ \\
& PhD Student & $(n=118 / 509)$ \\
& $15.91 \%$ \\
& $(n=81 / 509)$ \\
& & $3.73 \%$ \\
& & $(n=19 / 509)$ \\
\hline
\end{tabular}

After receiving responses to the survey with a completion rate of $100 \%$, the data collected from the survey were compiled to obtain the following answers to the research questions in this paper. 


\subsection{What Is Students' Perception of Cheating and Plagiarism on Assignments?}

Students were asked to report their understanding on four yes/no questions regarding the perception of the cheating investigated. Figure 1 shows that a certain number of students were not aware of the definition of cheating, the school's rules, nor the teacher's requirements for coursework.

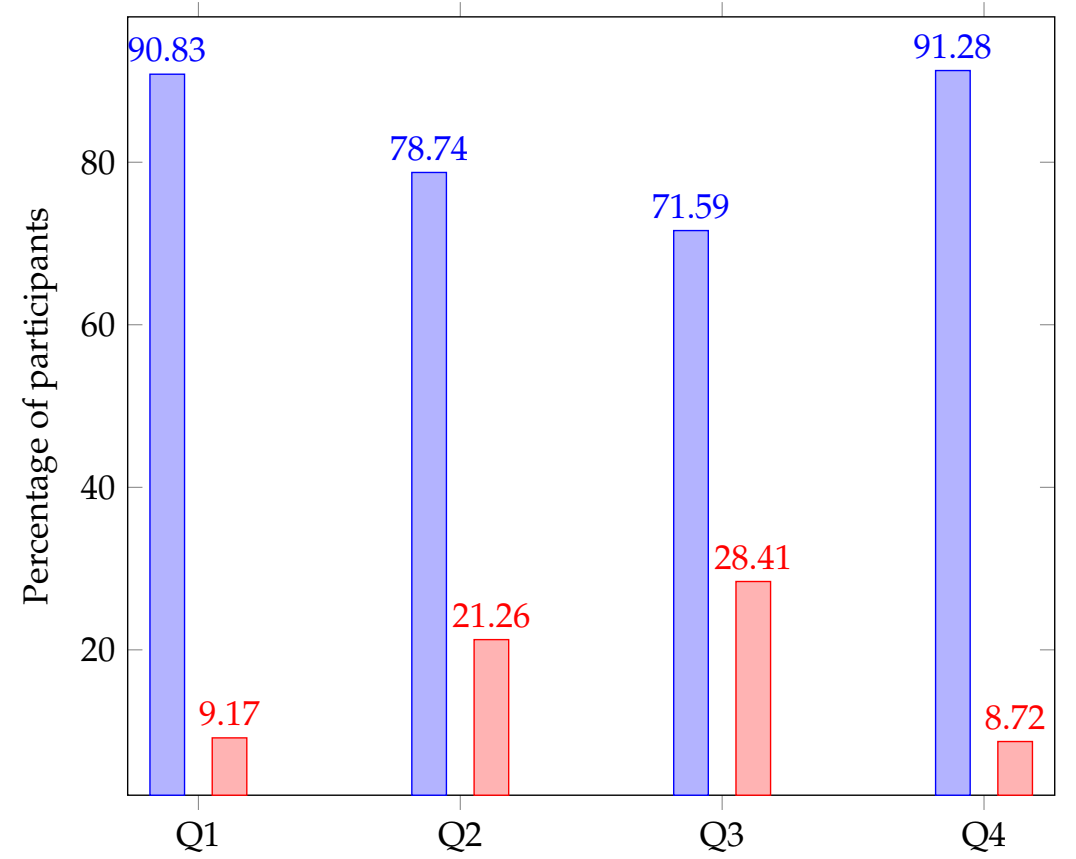

Figure 1. This figure shows the results of students' understanding and perceptions of cheating on coursework. Q1-Q4 represent Questions 1-4 in Table 1. The blue bars represent the percentage of students who understood the definition of cheating in the relevant coursework, university regulations, and teacher requirements for noncheating on assignments, respectively, while the red bars represent the percentage of students who did not understand or agree with the items in question.

For $9.17 \%$ of the students, they were not sure what plagiarism in coursework was. For $21.26 \%$ of the students, their institutions did not have a clear definition of cheating in the coursework. For $28.41 \%$ of the students who judged that their universities did not have clear penalties for cheating, $8.72 \%$ of the students thought that their lecturers did not clearly emphasize the rules of plagiarism and the consequences of violating them.

\subsection{How Likely Are Students from Different Years of University to Outsource Their Coursework?}

Regarding the main question of the study related to outsourcing behavior, the results showed that, overall, $71.14 \%$ of the students outsourced their coursework from web-based libraries, mobile Apps, essay mills, etc. Table 4 presents the details of the numbers and percentages for outsourcing behavior by using electronic resources in the different years of university. The participants responded to each item on a 4-point scale anchored by "Never (1)" and "Often (4)". A majority of students reported engaging in plagiarism and cheating less than 10 times $(54.81 \%)$. There were $7.61 \%$ of the students who released outsourcing coursework between 10 and 20 times, and $8.72 \%$ of the students outsourced frequently.

Specifically, the proportion of freshman students who did not outsource their coursework was the highest at $39.51 \%$, while the proportion who frequently outsourced their assignments was the lowest at $2.47 \%$. The percentage of students who outsourced their work increased as the year of university progressed. In the fourth year of university, more than $20 \%$ of students outsourced assignments more than 10 times. For Master's students, the percentage of outsourcing was even higher, with nearly $80 \%$ of students frequently obtaining answers directly from online resources. Although the number of doctoral students 
participating in the study was only 19,6 respondents $(31.58 \%)$ completed their assignments more than 10 times by obtaining answers directly from electronic resources.

Table 4. Frequency of student engagement in outsourcing their coursework from electronic resources (Baidu Library, ZhifouUniversity App, file-sharing sites, peer-sharing sites, essay factories, etc.) by year of university.

\begin{tabular}{|c|c|c|c|c|c|c|}
\hline & Never & $<10$ Times & 10-20 Times & Often & Mean & SD \\
\hline Freshman & $\begin{array}{c}39.51 \% \\
(n=32 / 81)\end{array}$ & $\begin{array}{c}53.09 \% \\
(n=43 / 81)\end{array}$ & $\begin{array}{c}4.93 \% \\
(n=4 / 81)\end{array}$ & $\begin{array}{c}2.47 \% \\
(n=2 / 81)\end{array}$ & 1.70 & 0.68 \\
\hline Sophomore & $\begin{array}{c}35.90 \% \\
(n=28 / 78)\end{array}$ & $\begin{array}{c}55.13 \% \\
(n=43 / 78)\end{array}$ & $\begin{array}{c}1.28 \% \\
(n=1 / 78)\end{array}$ & $\begin{array}{c}7.69 \% \\
(n=6 / 78)\end{array}$ & 1.81 & 0.81 \\
\hline Junior & $\begin{array}{c}27.14 \% \\
(n=19 / 70)\end{array}$ & $\begin{array}{c}57.14 \% \\
(n=40 / 70)\end{array}$ & $\begin{array}{c}5.71 \% \\
(n=4 / 70)\end{array}$ & $\begin{array}{c}10 \% \\
(n=7 / 70)\end{array}$ & 1.98 & 0.86 \\
\hline Senior & $\begin{array}{c}22.88 \% \\
(n=27 / 118)\end{array}$ & $\begin{array}{c}56.78 \% \\
(n=67 / 118)\end{array}$ & $\begin{array}{c}13.56 \% \\
(n=16 / 118)\end{array}$ & $\begin{array}{c}6.78 \% \\
(n=8 / 118)\end{array}$ & 2.04 & 0.80 \\
\hline Graduate Student & $\begin{array}{c}20.99 \% \\
(n=17 / 81)\end{array}$ & $\begin{array}{c}55.56 \% \\
(n=45 / 81)\end{array}$ & $\begin{array}{c}7.41 \% \\
(n=6 / 81)\end{array}$ & $\begin{array}{c}16.05 \% \\
(n=13 / 81)\end{array}$ & 2.19 & 0.95 \\
\hline PhD Student & $\begin{array}{c}31.58 \% \\
(n=6 / 19)\end{array}$ & $\begin{array}{c}36.84 \% \\
(n=7 / 19)\end{array}$ & $\begin{array}{c}15.79 \% \\
(n=3 / 19)\end{array}$ & $\begin{array}{c}15.79 \% \\
(n=3 / 19)\end{array}$ & 2.16 & 1.07 \\
\hline Subtotal & $\begin{array}{c}28.86 \% \\
(n=129 / 447)\end{array}$ & $\begin{array}{c}54.81 \% \\
(n=245 / 447)\end{array}$ & $\begin{array}{c}7.61 \% \\
(n=34 / 447)\end{array}$ & $\begin{array}{c}8.72 \% \\
(n=39 / 447)\end{array}$ & 1.96 & 0.84 \\
\hline
\end{tabular}

In addition, Table 4 also offers the means and standard deviations for the outsourcing scores. The overall mean value was 1.96 , and the standard deviation was 0.84 , indicating that students frequently outsource assignments between 10 and 20 times. Clearly, the results in the freshman year $(M=1.70 ; \mathrm{SD}=0.68)$ were the lowest. Again, with the increase in the year of university, the means and standard deviations increased. The mean for fourthyear students was more than 2.0; the highest mean for Master's students and doctoral students surmounted 2.1; and the standard deviation for doctoral students exceeded 1 . This shows a greater likelihood that older college students would often outsource assignments, thereby engaging in plagiarism and cheating.

\subsection{What Effect Does Cheating and Noncheating Have on Student Learning Outcomes?}

We analyzed the impact of cheating and noncheating on student learning outcomes in the following three aspects: students' final course grades, students' satisfaction with their completed assignments, and students' achievements by completing their course work. In Chinese universities, students' final grades generally consist of attendance, grades on regular assignments, and final exam results. The grades of regular assignments usually account for about $30-40 \%$ of the final grade. If regular assignments were outsourced and plagiarized, this would have a more significant impact on the course grade. Furthermore, frequent plagiarism may lead to poor understanding of the course and application of knowledge; then, students would be less likely to receive a good grade in the final exam. Furthermore, students who sought to outsource the completion of their assignments would have a negative attitude towards their coursework and correspondingly less satisfaction, as well as lower accomplishment from their coursework.

In Table 5, we report the effect of cheating on students' final course grades. The 5-point scale ranging from failure (1) to excellent (5) was used to quantify the final grades. To provide a reference point, the distribution of the final grades for students who did not engage in contract cheating is reported in Row 2. Clearly, the results in the table show that students who did not engage in plagiarism tended to perform better than those who did, with $51.16 \%$ reporting distinction. However, for students who outsourced assignments 20 times or less, their grades were predominantly first-class. Conversely, the final grades of students who frequently outsourced assignments were mainly concentrated between pass and first-class $(M=3.82, \mathrm{SD}=1.07)$. 
Table 5. The distribution of final course grades by frequency of student engagement in cheating.

\begin{tabular}{|c|c|c|c|c|c|c|c|}
\hline & Excellent & Good & Satisfactory & Poor & Failure & Mean & SD \\
\hline Never & $\begin{array}{c}51.16 \% \\
(n=66 / 129)\end{array}$ & $\begin{array}{c}35.66 \% \\
(n=46 / 129)\end{array}$ & $\begin{array}{c}10.85 \% \\
(n=14 / 129)\end{array}$ & $\begin{array}{c}2.33 \% \\
(n=3 / 129)\end{array}$ & $\begin{array}{c}0.00 \% \\
(n=0 / 129)\end{array}$ & 4.36 & 0.77 \\
\hline$<10$ times & $\begin{array}{c}28.16 \% \\
(n=69 / 245)\end{array}$ & $\begin{array}{c}53.06 \% \\
(n=130 / 245)\end{array}$ & $\begin{array}{c}14.29 \% \\
(n=35 / 245)\end{array}$ & $\begin{array}{c}4.08 \% \\
(n=10 / 245)\end{array}$ & $\begin{array}{c}0.41 \% \\
(n=1 / 245)\end{array}$ & 4.04 & 0.79 \\
\hline 10-20 times & $\begin{array}{c}50.00 \% \\
(n=17 / 34)\end{array}$ & $\begin{array}{c}32.35 \% \\
(n=11 / 34)\end{array}$ & $\begin{array}{c}8.82 \% \\
(n=3 / 34)\end{array}$ & $\begin{array}{c}8.82 \% \\
(n=3 / 34)\end{array}$ & $\begin{array}{c}0.00 \% \\
(n=0 / 34)\end{array}$ & 4.24 & 0.96 \\
\hline Often & $\begin{array}{c}30.77 \% \\
(n=12 / 39)\end{array}$ & $\begin{array}{c}35.90 \% \\
(n=14 / 39)\end{array}$ & $\begin{array}{c}20.51 \% \\
(n=8 / 39)\end{array}$ & $\begin{array}{c}10.26 \% \\
(n=4 / 39)\end{array}$ & $\begin{array}{c}2.56 \% \\
(n=1 / 39)\end{array}$ & 3.82 & 1.07 \\
\hline
\end{tabular}

We measured students' satisfaction levels with their completed submissions by using a 5-point Likert scale ("Very satisfied (5)" and "Very dissatisfied (1)"). Figure 2 plots the results of students' satisfaction with their completed assignments. It is obvious from the graph that students who did not participate in cheating and plagiarism were highly satisfied with their completed assignments, with $47.29 \%$ being very satisfied. The higher the frequency of students involved in cheating, the less satisfied they were with their assignments. The students who cheated frequently were dissatisfied with their completed assignments at $15.38 \%$. Thus, satisfaction with assignments was inversely related to the frequency of cheating.

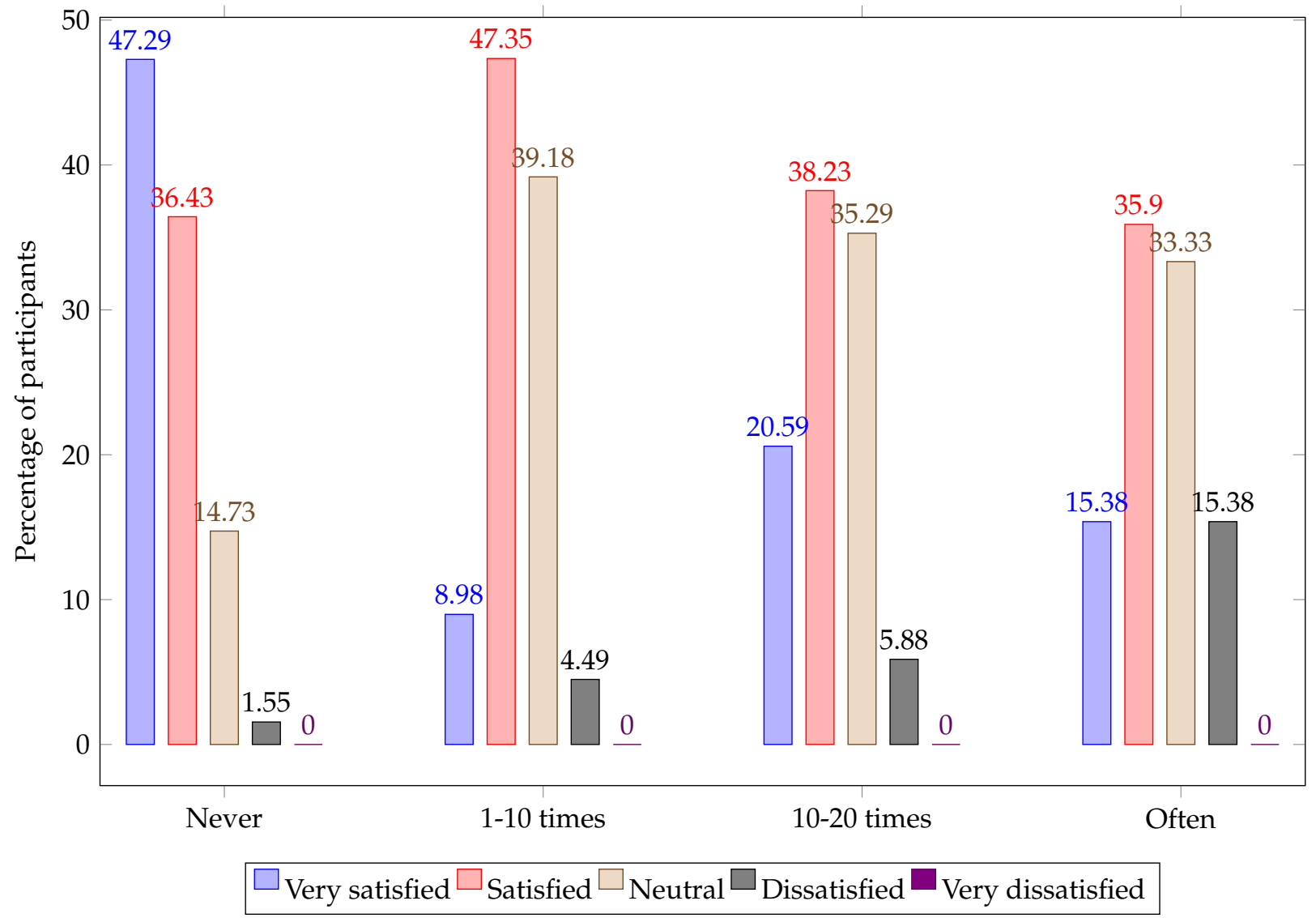

Figure 2. The satisfaction levels with their completed submissions by different frequencies of student engagement in cheating.

Finally, Figure 3 reports the inner experiences and sense of accomplishments that students gained through completing their coursework. Positive gains, improving understanding and learning and building self-confidence in the course, decreased with the increase in the frequency of cheating. On the other hand, the negative gains, learning nothing and wasted effort, increased as the amount of cheating increased. There were $92.25 \%$ 
of the noncheaters who believed that the assignments deepened their understanding and learning of the course; only $0.78 \%$ of the noncheaters thought that the assignments were a waste of time; and 3.1\% of the noncheaters believed that they did not learn anything. For the students who cheated frequently, $28.21 \%$ felt that nothing was learned, and $20.51 \%$ sensed that was a negative experience of wasting time.

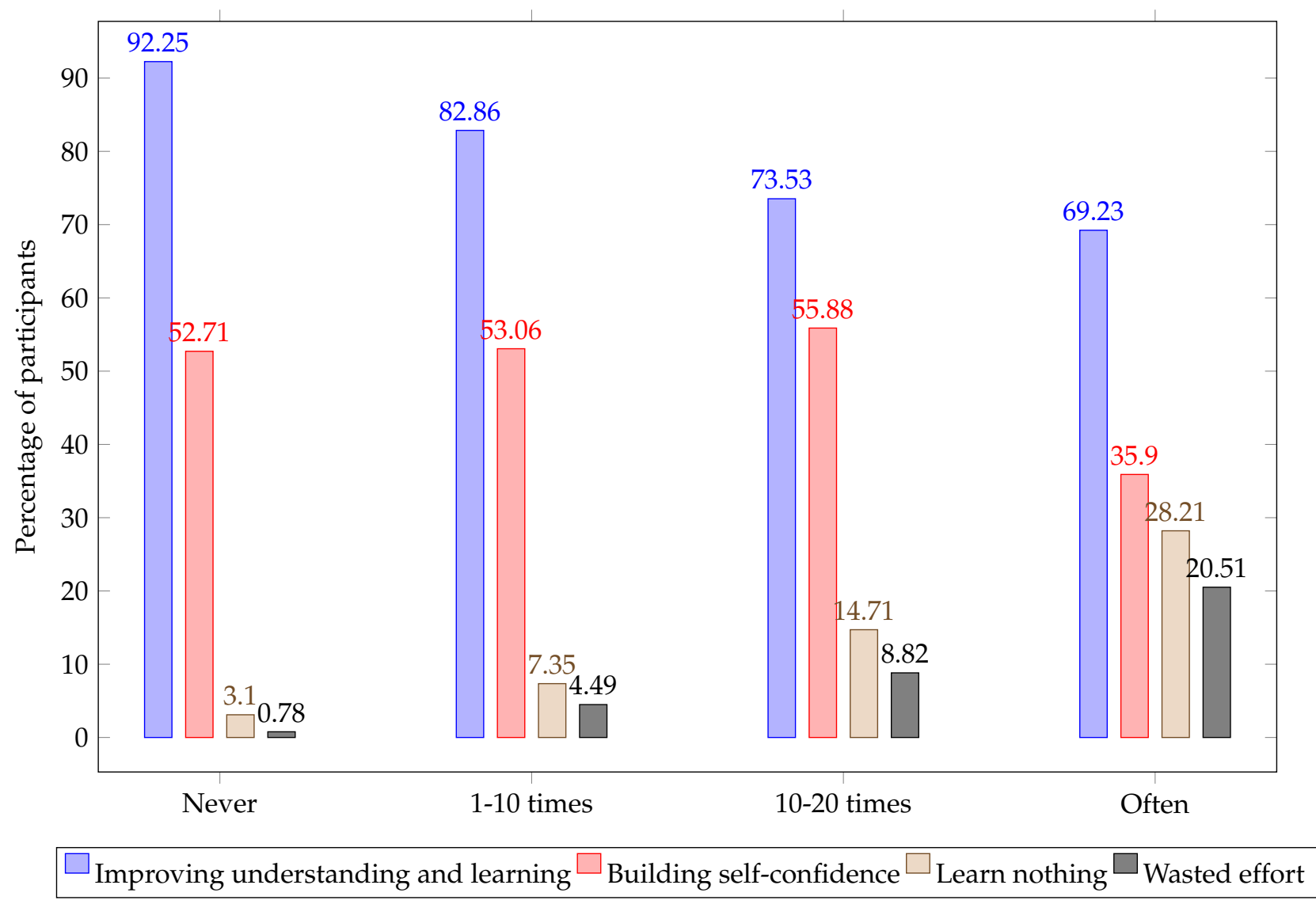

Figure 3. The different accomplishments achieved from the coursework by the different frequencies of student engagement in cheating.

\subsection{How Do Educators Perceive and Respond to the Behaviors of Contract Cheating?}

Teachers are the primary perceivers of cheating and plagiarism as they need to review students' coursework. As shown in Table 6, only one teacher felt that students did not plagiarize their assignments. There were $41.91 \%$ of the teachers $(n=26)$ who sensed that $30 \%$ of assignment submissions had plagiarism, while $32.26 \%$ of teachers $(n=20)$ recognized that half of the assignments had cheating problems.

Table 6. Percentages of plagiarized coursework accounting for the total amount of coursework by the perceptions of teachers.

\begin{tabular}{ccccccc}
\hline $\mathbf{0} \%$ & $\mathbf{1 0} \%$ & $\mathbf{3 0} \%$ & $\mathbf{5 0 \%}$ & $\mathbf{7 0 \%}$ & $\mathbf{9 0} \%$ & $\mathbf{1 0 0} \%$ \\
\hline $1(1.61 \%)$ & $9(14.52 \%)$ & $26(41.91 \%)$ & $20(32.26 \%)$ & $3(4.84 \%)$ & $3(4.84 \%)$ & $0(0.00 \%)$ \\
\hline
\end{tabular}

Furthermore, Figure 4 shows the results of teachers' perceptions of and responses to student involvement in cheating behavior. Surprisingly, a small percentage of the teachers who participated in the survey did not even understand what plagiarism and cheating on assignments were. There were $53.23 \%$ of the educators who realized that their institutions had no clear guides and regulations on plagiarism with respect to assignments. For $66.13 \%$ of the teachers, their universities did not have clear penalties for cheating. There were 
$25.11 \%$ of the teachers who admitted that they did not clearly emphasize the rules of plagiarism in the classes. A whopping $80.65 \%$ of teachers reported that their universities did not have automatic plagiarism-detection software for students' assignments and coursework. There were $33.87 \%$ of the teachers who did not give feedback to students when there was plagiarism in their coursework submissions. There were $40.32 \%$ of the teachers who did not design a creative learning environment to reduce the likelihood of students' cheating behavior.

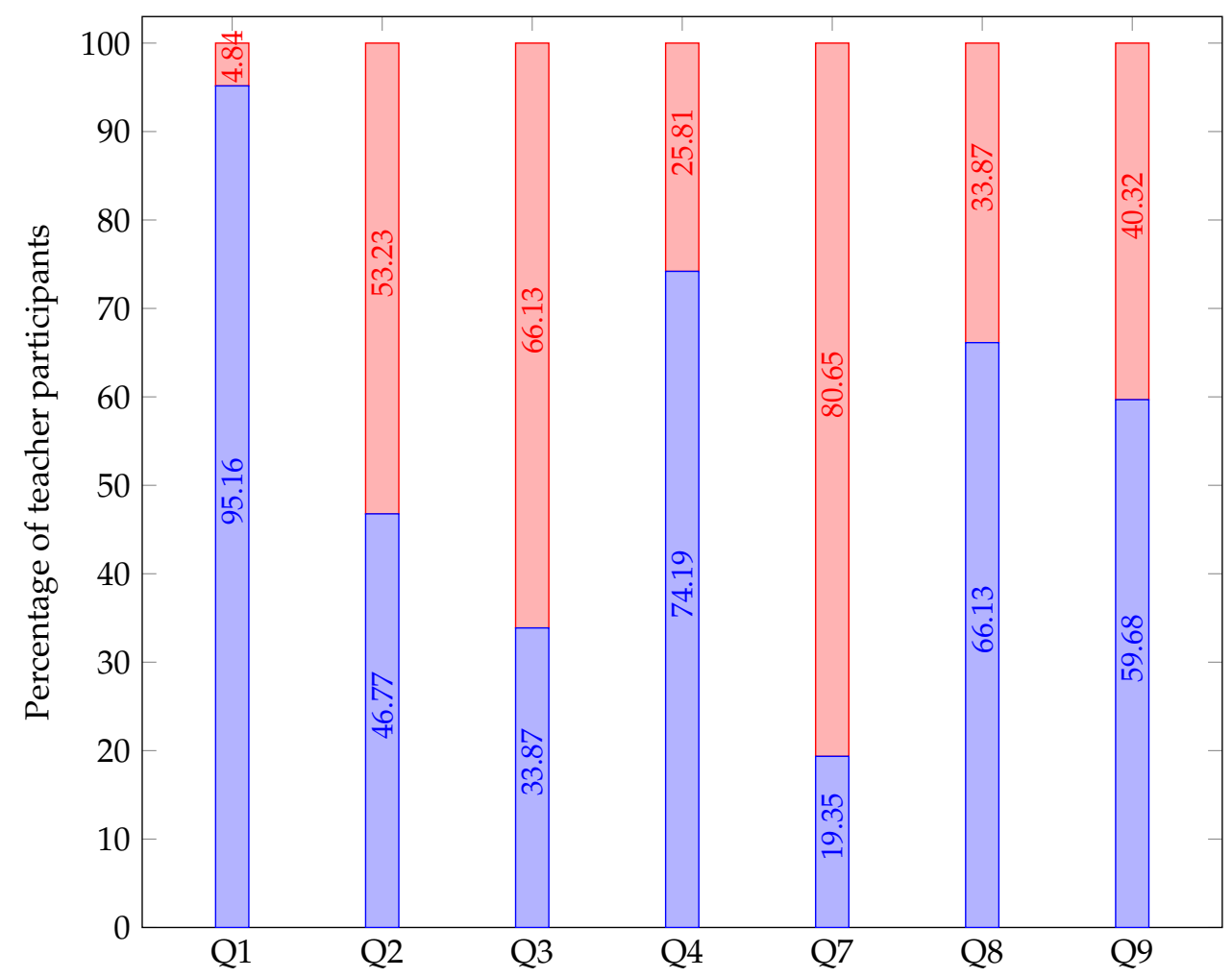

Figure 4. This figure shows the results of educators' perceptions of and responses to student engagement in cheating. Q1-Q4 and Q7-Q9 represent Questions 1-4 and 7-9 in Table 2, respectively. The bottom bar represents the percentages of educators who understood the definition of cheating, whose universities had clear regulations and penalization rules, who emphasized cheating rules in the class, whose institutions have cheat-detection software tools, who given feedback to students when there was plagiarism in their coursework submissions, and who designed creative learning environments, respectively, while the top bars indicate the opposite results.

\subsection{What Are the Motivating Factors for Cheating Behaviors?}

In order to explore the drivers of plagiarism behaviors, Pearson's correlation coefficients were used to analyze, on a case-by-case basis, the random relationships among plagiarism and individual, institutional, teaching, and learning outcome factors. The test results are reported in Table 7, with the dependent variable for each potential factor being whether the student agreed with the item (1) or disagreed (0). When the result of the test decision is in bold, the test supports the association between plagiarism and the relevant factors. 
Table 7. The results of the linear correlation test. For electronic plagiarism behaviors, the individual factors, institutional factors, teaching factors, and learning factors investigated are listed, including their Pearson's correlation coefficients and $p$-values. The results in bold indicate that the test supports a good correlation between plagiarism behaviors and the related factors at the $5 \%$ significance level.

\begin{tabular}{|c|c|c|c|}
\hline & & $\begin{array}{l}\text { Correlation } \\
\text { Coefficient }\end{array}$ & $p$-Values \\
\hline \multirow{6}{*}{ Individual factors } & Understand the definition of plagiarism & -0.0484 & 0.3067 \\
\hline & Desire to receive a good final course grade & 0.1309 & 0.0055 \\
\hline & Poor time management & 0.0652 & 0.1682 \\
\hline & Disinterest in the course assignment & 0.0392 & 0.4081 \\
\hline & Fear of failure & 0.0059 & 0.9011 \\
\hline & Coursework is too easy & -0.0235 & 0.6199 \\
\hline \multirow{3}{*}{ Institutional factors } & $\begin{array}{c}\text { Clear regulations on plagiarism in } \\
\text { coursework }\end{array}$ & & 0.0035 \\
\hline & Penalization for plagiarism & -0.1275 & 0.0069 \\
\hline & Plagiarism-detection tools & -0.1186 & 0.0121 \\
\hline \multirow{6}{*}{ Teaching factors } & $\begin{array}{c}\text { Lecturers have highlighted plagiarism in } \\
\text { their courses }\end{array}$ & -0.0744 & 0.1160 \\
\hline & $\begin{array}{l}\text { Lecturers give feedback on plagiarized } \\
\text { assignments }\end{array}$ & -0.1510 & 0.0014 \\
\hline & $\begin{array}{c}\text { Lecturers design creative learning } \\
\text { environments }\end{array}$ & -0.0589 & 0.2142 \\
\hline & Lecturers review assignments carefully & -0.0528 & 0.2652 \\
\hline & $\begin{array}{l}\text { Teachers make lectures interesting and } \\
\text { lively }\end{array}$ & 0.0131 & 0.7822 \\
\hline & $\begin{array}{l}\text { Teachers themselves have committed } \\
\text { plagiarism, such as copying lecture notes. }\end{array}$ & 0.0573 & 0.2269 \\
\hline \multirow{6}{*}{ Learning factors } & Satisfaction with reviews of submissions & -0.0807 & 0.0879 \\
\hline & $\begin{array}{l}\text { Satisfaction with their completed } \\
\text { coursework }\end{array}$ & -0.2619 & $<0.0001$ \\
\hline & Doing coursework improves learning & -0.1478 & 0.0017 \\
\hline & Doing coursework builds confidence & -0.0131 & 0.7808 \\
\hline & Learn nothing by doing coursework & 0.1233 & 0.0091 \\
\hline & Doing coursework is a waste of time & 0.1260 & 0.0076 \\
\hline
\end{tabular}

As shown in Table 7, nine factors were discovered, including the individual factors, which contained one aspect ("Desire to get a good final course grade"), the institutional factors, which contained all three points ("Clear regulations on plagiarism in coursework", "Penalization for plagiarism", and "plagiarism detection tools"), the teaching factor, which contained only a single item ("Lecturers provide feedback on plagiarized assignments"), and the learning factors, which contained four elements relating to satisfaction with assignments and accomplishments gained from the coursework. Compared to the other factors, "satisfaction with completion of coursework" had the highest correlation coefficient, with a value of -0.2619 . This value breaks our conventional understanding of contractual plagiarism and indicates that students have high expectations of their performance and expect to complete assignments well.

\subsection{Interpretation of the Results by Using Partial-Least-Squares Regression}

Figure 5 plots the percent of variance explained in the frequency of contract cheating variable $y$ as a function of the number of PLS components. The results suggest that PLSR with seven components can explain most of the variance in the data of $y$. Therefore, the fitted response values of the PLSR were computed by using the seven-component model. 


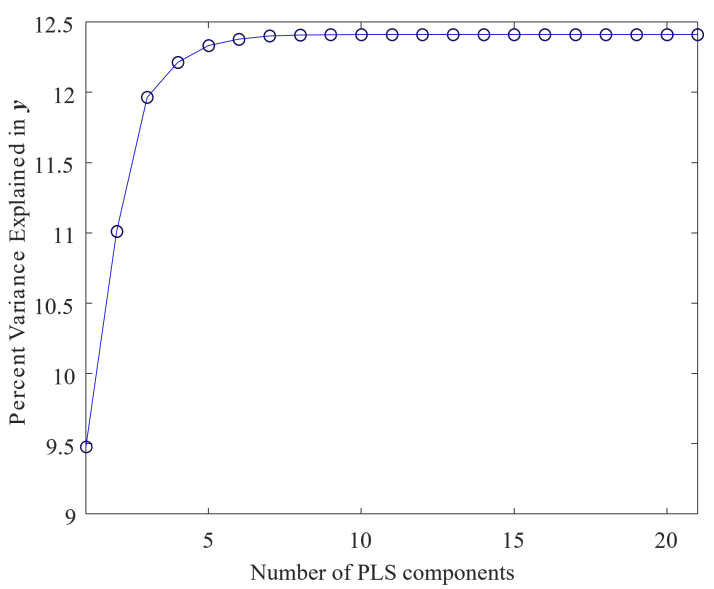

(a)

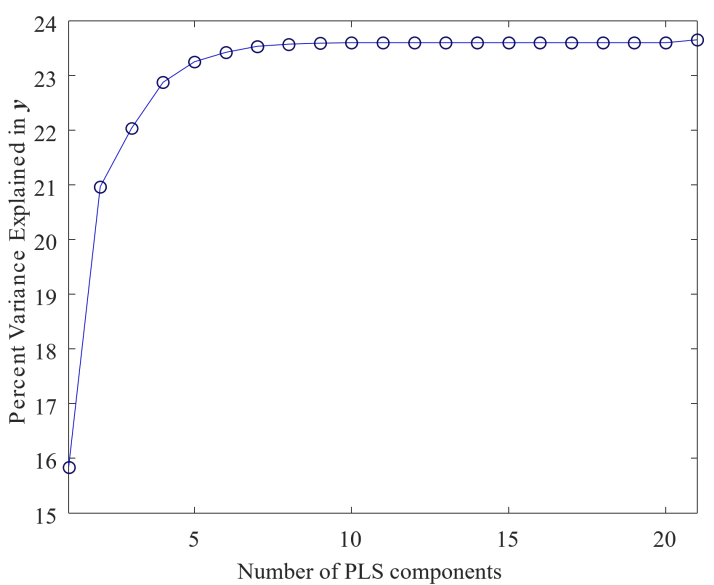

(b)

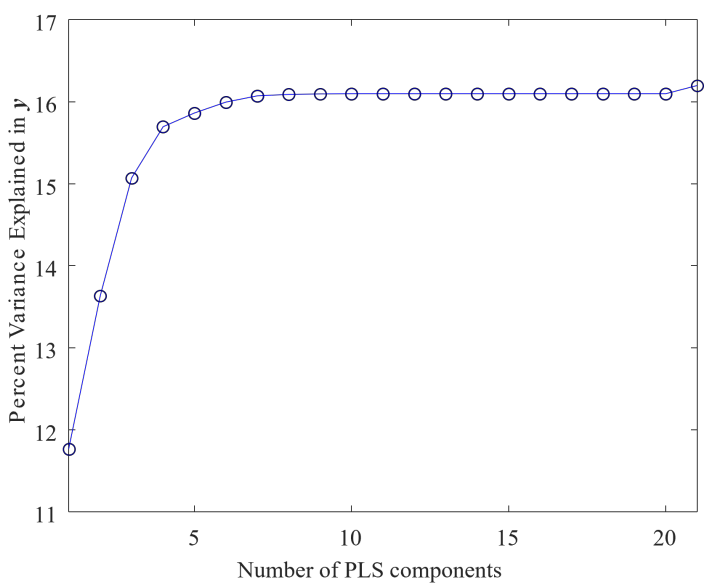

(c)

Figure 5. Percent of variance explained in $y$ with respect to the number of PLS components: (a) The data of the all participant; (b) the data of the student participants from the UCAS, first-class, and national key universities; and (c) the data of the students from the ordinary universities.

The different regression coefficients created by PLS are given in Figure 6. For the all sample data, the examination of the seven-dimensional regression coefficients showed that the factors including clear regulations on plagiarism in coursework (F2), teachers themselves have committed plagiarism (F11), lecturers give feedback on plagiarized assignments (F12), use of plagiarism detection tools (F13), learn nothing by doing coursework 
(F20), and doing coursework is a waste of time (F21) were mainly responsible for the frequency of the contract cheating.

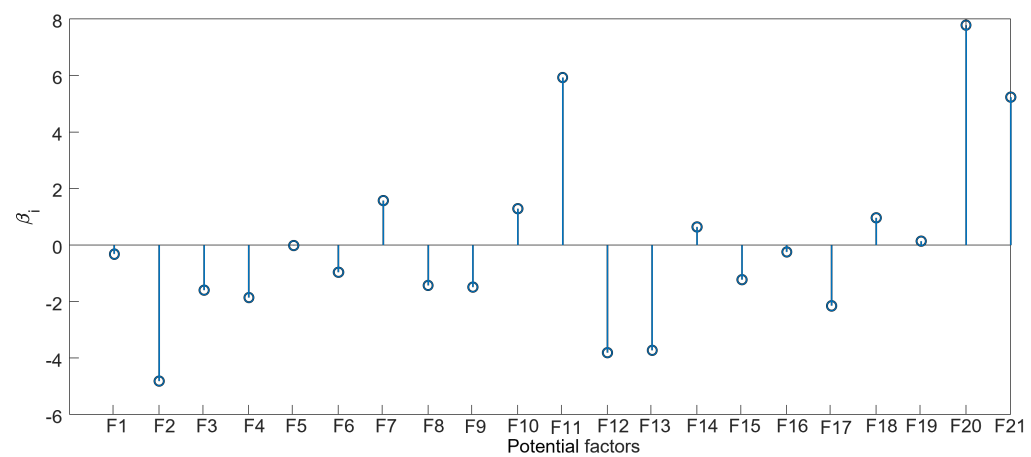

(a)

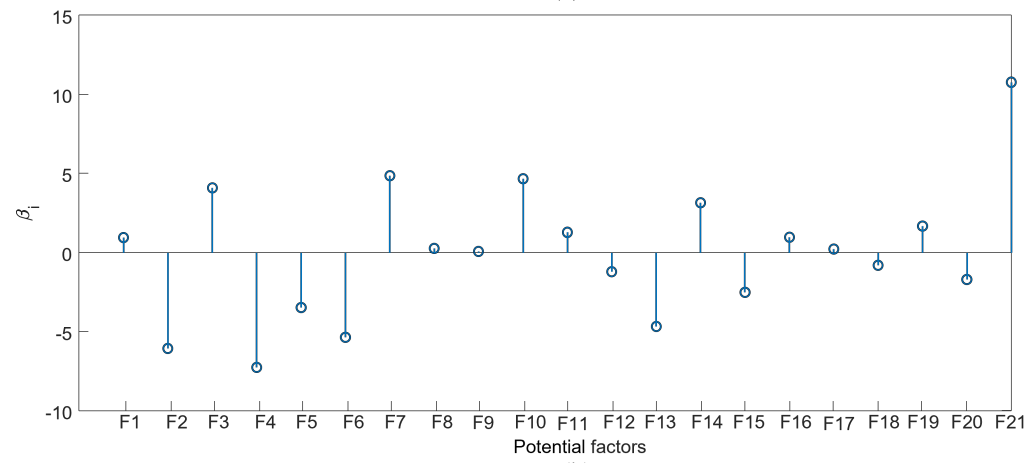

(b)

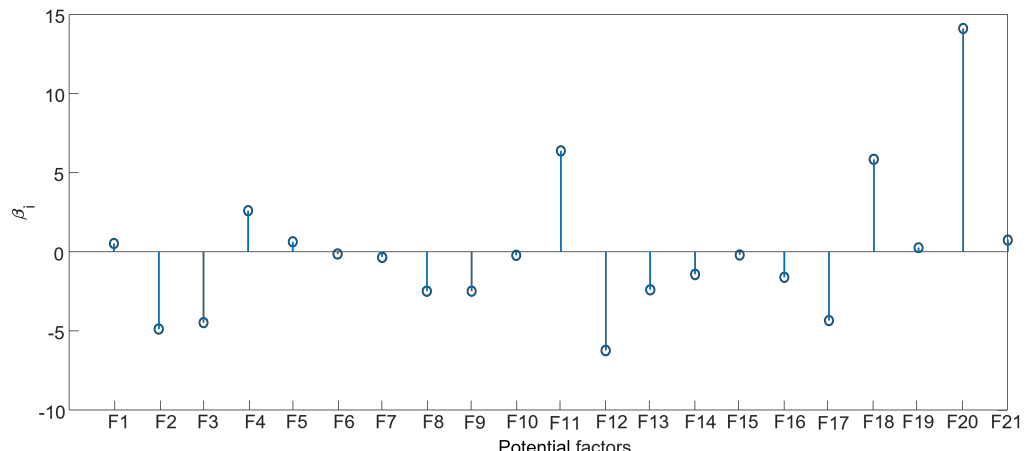

(c)

Figure 6. The regression coefficients with respect to the potential factors: (a) The data of the all participant; (b) the data of the student participants from the UCAS, first-class, and national key universities; and (c) the data of the student participants from the ordinary universities. The potential factors are denoted as follows: students understand what plagiarism is (F1), clear regulations on plagiarism in coursework (F2), penalization for plagiarism (F3), lecturers have highlighted plagiarism in their courses (F4), weather teachers make lectures interesting and lively (F5), disinterest in the course assignment (F6), desire to receive a good final course grade (F7), poor time management (F8), fear of failure (F9), coursework is too easy (F10), teachers themselves have committed plagiarism, such as copying lecture notes (F11), lecturers give feedback on plagiarized assignments (F12), use of plagiarism detection tools (F13), lecturers design creative learning environments (F14), lecturers review assignments carefully (F15), satisfaction with teachers' reviews of submissions (F16), satisfaction with their completed coursework (F17), doing coursework improves learning (F18), doing coursework builds confidence (F19), learn nothing by doing coursework (F20), and doing coursework is a waste of time (F21).

Next, the data were divided into two groups in order to examine the response patterns of different types of institutions. One group consisted of student participants from the 
UCAS, first-class universities, and national key universities, and the other group consisted of student participants from the ordinary universities. As shown in Figure 6b, the regression coefficients indicated that the frequency of contract cheating was highly dependent on the teaching methods of the teachers and the interest of the individuals in the respective courses. This is because these excellent universities have bright and hardworking students. Students have higher expectations of their teachers, so they consider it very important that their lectures are interesting and lively. In contrast, the regression coefficient for the factor of learning nothing by doing coursework (F20) was positively correlated with the frequency of contract cheating among the students at the ordinary universities, and teachers also copying lecture notes from the Internet (F12) was highly correlated with it.

\section{Discussion}

Cheating occurs in universities all over the world [36,37], such as plagiarism on assignments and cheating on exams. The purpose of this study was to statistically explore the perceptions of contract cheating on assignments, related experiences, potential factors, and learning outcomes with contract cheating in coursework among Chinese university students and responses to contract cheating by educators and institutions in the digital age.

According to the findings of the study, while $90.83 \%$ (see Figure 1 ) of the students understood what cheating behavior was, $71.14 \%$ (see Table 4 ) admitted to having 10 or more experiences of outsourcing coursework. Students may believe that plagiarism and cheating are not a serious violation, considering that electronic resources from third parties are shared information and therefore can be copied directly without citation [38].

The results in Table 4 indicate that freshmen outsourced assignments less frequently than other more senior students. As year of college increases, the proportion of students who outsourced assignments increases, and even graduate students have more severe outsourcing practices. This suggests a need for training freshmen on the academic code of conduct for coursework at the time of university orientation. Students did not undergo training through formal lectures and a tutorial exercise to teach them about plagiarism; they demonstrated poor training in citation skills, poor supervision, and academic weakness and were most likely to use contract cheating. In a study of U.K. higher education textbooks, Reference [39] analyzed source texts for postgraduate certificates in higher education at U.K. universities. They found that the concept of academic integrity needs to be integrated into mainstream discourse around teaching in U.K. higher education.

Despite some interventions in academic writing and referencing and plagiarism tutorials, a quarter of students were still commit plagiarism in their essay assignments [40]. This is not surprising, since curbing contract cheating requires supervision by educators and a concerted effort by universities.

Considering student understandings and engagements with contract cheating, as well as policies and methods across the world, there are great differences in attitudes towards cheating in different countries. These factors make it critical for an institution to teach clear standards of academic integrity, because in many cases, there is no clear definition of academic dishonesty practices. Many Chinese students and teachers who participated in this survey understood that their institutions did not have clear guides, regulations, and penalties for plagiarism and cheating on coursework. Therefore, all stakeholders in the university, especially students, teaching staff, and faculty management, have a responsibility to minimize the incidents of contract cheating. This is consistent with the finding of [41]. Lambert et al. [41], who reported that academic dishonesty is frequent among New Zealand university students, although few incidents were handled with the formal practices that were set out in institutional policy manuals. Colnerud and Rosander [42] discovered the implicit logic in the Swedish students' attitudes: the lower the level of effort and work, the lower the level of learning that can be expected; the lower the level of learning, the higher the level of academic cheating is.

Due to the widespread use of electronic resources from third parties, it is unlikely that plagiarism detection for each assignment can be performed manually by the teacher 
alone. As a result, $33.87 \%$ of the teachers did not provide feedback to the students about the plagiarism of their assignments (see Figure 4). This is so bad in that it leads the students to believe that plagiarism can be negotiable and ignorable. An automatic and efficient method of identifying plagiarism using electronic online detection software is necessary. There were $80.65 \%$ of the teachers who realized that their universities did not have software tools to detect plagiarism in assignments. According to current public reports, only Tsinghua University in China provides software that automatically detects the repetition rate for daily assignments $[3,43]$. In the Chinese context, there is a distinct lack of advice given to students, which needs to be addressed as most of the students who participated in the study of [44] claimed not to have received any instructions, feedback, nor alerts.

A unique contribution of this study is that potential factors related to plagiarism behavior were assessed using Pearson's correlation coefficient. The drive of the Chinese student's individual factors, such as the expectation of a desired final course grade, satisfaction with his or her completion of the assignments, and learning outcomes, all play a role in determining whether a student cheats on coursework. All three items of institutional factors, clear regulations, penalization, and automatic detection of plagiarism, strongly influenced the behaviors leading to electronic plagiarism. Teacher feedback also acts as a deterrent for students from cheating on assignments.

In summary, the current results of the sample analysis reveal the motivational causes of contract cheating to a certain extent and provide relevant references for strengthening relevant instructional management in the future. However, there are two potential limitations of this study: first, the amount of data collected was small, which makes the indicative meaning of the findings of this study somewhat limited. In addition, it is not possible to determine whether the survey volunteers who participated in the survey about cheating tried to answer the relevant cheating questions as objectively as possible. In particular, there is a certain bias in such surveys when cheaters themselves report that they cheat. Therefore, only a statistical analysis after a large sample has been collected can eliminate the effects of these biases.

\section{Conclusions}

This paper explored the frequencies, reasons, and related learning outcomes of Chinese college students' engagement in outsourcing academic coursework. Two parallel surveys of students and educators were conducted simultaneously. Statistical analysis of survey data from both educators and learners deepened our understanding of contract cheating in Chinese universities.

To summarize this study, our findings suggested that both personal and institutional reasons significantly influence cheating intentions. Internal motivations for students' cheating intention were the expectation of a good final course grade, dissatisfaction with learning outcomes, and little sense of accomplishment. External motivations were inadequate feedback from teachers on assignments with cheating and a lack of institutional regulations and cheating-detection software tools. The results of the study point to the necessity of implementing courses that address academic integrity in the first year of university, building clear institutional regulations, and developing automatic detection software, which clearly have the potential to deter contract cheating behaviors.

There are some potential limits to this study. Although we tried to invite anonymous volunteers to participate in the questionnaire as much as possible, the number of collected survey data was not large enough in the end. In the future, our work will fill this gap. Overall, the data and statistical analysis results of the thesis can provide a positive reference for reducing contract cheating in Chinese universities. In addition, the proposed methodology may also provide universities an effective way to dynamically measure and evaluate changes in university management practices in response to contract cheating over time.

Author Contributions: Conceptualization, Z.X. and Y.W.; methodology, Y.W. and Z.X.; computer programming, Z.X.; writing and revisions, Y.W. and Z.X. Both authors have read and agreed to the published version of the manuscript. 
Funding: This research was funded by the Scientific Research Start-up Foundation for Talent Introduction of Nantong University Grant No.19R87.

Acknowledgments: The authors wish to extend our profound gratitude to the Academic Editors, Gregorio Giménez and Javier Valbuena, and the anonymous reviewers for their careful review and invaluable comments, which significantly improved the quality of this article.

Conflicts of Interest: The authors declare no conflict of interest.

\section{References}

1. Zhang, C. 81 College Students Plagiarized Their Coursework; China News Service: 2018. Available online: http://www.gx.chinanews. $\mathrm{com} /$ news/2018/0726/26327.html (accessed on 24 June 2021)

2. Kong, L. 22 Students Plagiarized the Final Works, ASSOCIATE Professor Su from the University of the Chinese Academy of Sciences Issued a 0-Point Score Announcement; Beijing Youth Daily: Beijing, Chnia, 2018. Available online: http://m.cyol.com/content/2018 -09/16/content_17585860.htm (accessed on 24 June 2021).

3. Zuo, M. How Chinese Universities Are Tackling Plagiarism-And Is It Working? South China Morning Post: 2019. Available online: https:/ / www.scmp.com/news/china/society/article/3012741/how-chinese-universities-are-trapping-academic-copycats (accessed on 24 June 2021).

4. Clarke, R.; Lancaster, T. Eliminating the successor to plagiarism? Identifying the usage of contract cheating sites. In Proceedings of the 2nd International Plagiarism Conference, Gateshead, UK, 19-21 June 2006.

5. $\quad$ Bretag, T.; Harper, R.; Burton, M.; Ellis, C.; Newton, P.; van Haeringen, K.; Saddiqui, S.; Rozenberg, P. Contract cheating and assessment design: Exploring the relationship. Assess. Eval. High. Educ. 2019, 44, 676-691. [CrossRef]

6. Ellis, C.; van Haeringen, K.; Harper, R.; Bretag, T.; Zucker, I.; McBride, S.; Rozenberg, P.; Newton, P.; Saddiqui, S. Does authentic assessment assure academic integrity? Evidence from contract cheating data. High. Educ. Res. Dev. 2020, 39, 454-469. [CrossRef]

7. Badge, J.L.; Cann, A.J.; Scott, J. To cheat or not to cheat? A trial of the JISC plagiarism detection service with biological sciences students. Assess. Eval. High. Educ. 2007, 32, 433-439. [CrossRef]

8. Butakov, S.; Scherbinin, V. The toolbox for local and global plagiarism detection. Comput. Educ. 2009, 52, 781-788. [CrossRef]

9. Yang, F.P.; Jiau, H.C.; Ssu, K.F. Beyond plagiarism: An active learning method to analyze causes behind code-similarity. Comput. Educ. 2014, 70, 161-172. [CrossRef]

10. Newton, P.M. How common is commercial contract cheating in higher education and is it increasing? A systematic review. Front. Educ. 2018, 67, 1-18. [CrossRef]

11. Lines, L. Substantive editing as a form of plagiarism among postgraduate students in Australia. Assess. Eval.High. Educ. 2016, 41, 368-383. [CrossRef]

12. Rowland, S.; Slade, C.; Wong, K.S.; Whiting, B. 'Just turn to us': The persuasive features of contract cheating websites. Assess. Eval. High. Educ. 2018, 43, 652-665. [CrossRef]

13. Parks, R.F.; Lowry, P.B.; Wigand, R.T.; Agarwal, N.; Williams, T.L. Why students engage in cyber-cheating through a collective movement: A case of deviance and collusion. Comput. Educ. 2018, 125, 308-326. [CrossRef]

14. Peled, Y.; Eshet, Y.; Barczyk, C.; Grinautski, K. Predictors of Academic Dishonesty among undergraduate students in online and face-to-face courses. Comput.Educ. 2019, 131, 49-59. [CrossRef]

15. Duggan, F. Plagiarism: Prevention, practice and policy. Assess. Eval. High. Educ. 2006, 31, 151-154. [CrossRef]

16. Rasmussen, I.; Hagen, Å. Facilitating students' individual and collective knowledge construction through microblogs. Int. J. Educ. Res. 2015, 72, 149-161. [CrossRef]

17. Gentina, E.; Tang, T.L.P.; Dancoine, P.F. Does Gen Z's emotional intelligence promote iCheating (cheating with iPhone) yet curb iCheating through reduced nomophobia? Comput. Educ. 2018, 126, 231-247. [CrossRef]

18. Ellery, K. An investigation into electronic-source plagiarism in a first-year essay assignment. Assess. Eval. High. Educ. 2008, 33, 607-617. [CrossRef]

19. Liu, G.Z.; Lo, H.Y.; Wang, H.C. Design and usability testing of a learning and plagiarism avoidance tutorial system for paraphrasing and citing in English: A case study. Comput. Educ. 2013, 69, 1-14. [CrossRef]

20. Dawson, P.; Sutherland-Smith, W.; Ricksen, M. Can software improve marker accuracy at detecting contract cheating? A pilot study of the Turnitin authorship investigate alpha. Assess. Eval. High. Educ. 2020, 45, 473-482. [CrossRef]

21. Sefcik, L.; Striepe, M.; Yorke, J. Mapping the landscape of academic integrity education programs: What approaches are effective? Assess. Eval. High. Educ. 2020, 45, 30-43. [CrossRef]

22. Chirumamilla, A.; Sindre, G.; Nguyen-Duc, A. Cheating in e-exams and paper exams: The perceptions of engineering students and teachers in Norway. Assess. Eval. High. Educ. 2020, 45, 940-957. [CrossRef]

23. Tremayne, K.; Curtis, G.J. Attitudes and understanding are only part of the story: Self-control, age and self-imposed pressure predict plagiarism over and above perceptions of seriousness and understanding. Assess. Eval. High. Educ. 2021, 46, 208-219. [CrossRef]

24. Amigud, A.; Lancaster, T. 246 reasons to cheat: An analysis of students' reasons for seeking to outsource academic work. Comput. Educ. 2019, 134, 98-107. [CrossRef] 
25. Kauffman, Y.; Young, M.F. Digital plagiarism: An experimental study of the effect of instructional goals and copy-and-paste affordance. Comput. Educ. 2015, 83, 44-56. [CrossRef]

26. Koul, R. Multiple motivational goals, values, and willingness to cheat. Int. J. Educ. Res. 2012, 56, 1-9. [CrossRef]

27. Druică, E.; Vâlsan, C.; Ianole-Călin, R.; Mihail-Papuc, R.; Munteanu, I. Exploring the Link between Academic Dishonesty and Economic Delinquency: A Partial Least Squares Path Modeling Approach. Mathematics 2019, 7, 1241. [CrossRef]

28. Bretag, T.; Harper, R.; Burton, M.; Ellis, C.; Newton, P.; Rozenberg, P.; Saddiqui, S.; van Haeringen, K. Contract cheating: A survey of Australian university students. Stud. High. Educ. 2019, 44, 1837-1856. [CrossRef]

29. Bretag, T.; Harper, R.; Rundle, K.; Newton, P.M.; Ellis, C.; Saddiqui, S.; van Haeringen, K. Contract cheating in Australian higher education: A comparison of non-university higher education providers and universities. Assess. Eval. High. Educ. 2020, 45, 125-139. [CrossRef]

30. Amigud, A.; Lancaster, T. I will pay someone to do my assignment: An analysis of market demand for contract cheating services on twitter. Assess. Eval. High. Educ. 2020, 45, 541-553. [CrossRef]

31. Amigud, A. Cheaters on Twitter: An analysis of engagement approaches of contract cheating services. Stud. High. Educ. 2020, 45, 692-705. [CrossRef]

32. Awdry, R. Assignment outsourcing: Moving beyond contract cheating. Assess. Eval. High. Educ. 2021, 46, 220-235. [CrossRef]

33. Zhang, Y.; Yin, H. Collaborative cheating among chinese college students: The effects of peer influence and IndividualismCollectivism orientations. Assess. Eval. High. Educ. 2020, 45, 54-69. [CrossRef]

34. Patten, M.L.; Newhart, M. Understanding Research Methods: An Overview of the Essentials; Taylor \& Francis: Abingdon, UK, 2017.

35. Abdi, H. Partial least squares regression and projection on latent structure regression (PLS Regression). Wiley Interdiscip. Rev. Comput. Stat. 2010, 2, 97-106. [CrossRef]

36. Trost, K. Psst, have you ever cheated? A study of academic dishonesty in Sweden. Assess. Eval. High. Educ. 2009, 34, 367-376. [CrossRef]

37. Sutherland-Smith, W.; Dullaghan, K. You don't always get what you pay for: User experiences of engaging with contract cheating sites. Assess. Eval. High. Educ. 2019, 44, 1148-1162. [CrossRef]

38. Uzun, A.M.; Kilis, S. Investigating antecedents of plagiarism using extended theory of planned behavior. Comput. Educ. 2020, 144, 103700. [CrossRef]

39. Ransome, J.; Newton, P.M. Are we educating educators about academic integrity? A study of UK higher education textbooks. Assess. Eval. High. Educ. 2018, 43, 126-137. [CrossRef]

40. Ellery, K. Undergraduate plagiarism: A pedagogical perspective. Assess. Eval. High. Educ. 2008, 33, 507-516. [CrossRef]

41. De Lambert, K.; Ellen, N.; Taylor, L. Chalkface challenges: A study of academic dishonesty amongst students in New Zealand tertiary institutions. Assess. Eval. High. Educ. 2006, 31, 485-503. [CrossRef]

42. Colnerud, G.; Rosander, M. Academic dishonesty, ethical norms and learning. Assess. Eval. High. Educ. 2009, 34, 505-517. [CrossRef]

43. Hua, S. Tsinghua University: Launching a Service for Testing the Repetition Rate of Student Coursework; Tsinghua University: Beijing, Chnia, 2018. Available online: https:/ / news.tsinghua.edu.cn/info/1013/67731.htm (accessed on 24 June 2021).

44. Zhang, D.; Joy, M.; Cosma, G.; Boyatt, R.; Sinclair, J.; Yau, J. Source-code plagiarism in universities: A comparative study of student perspectives in China and the UK. Assess. Eval. High. Educ. 2014, 39, 743-758. [CrossRef] 